\title{
Occurrence of oral diseases in neotropical wild carnivores kept in captivity at the zoo from Federal University of Mato Grosso - Cuiabá
}

\section{Ocorrência de afecções orais em carnívoros selvagens neotropicais mantidos em cativeiro no zoológico da Universidade Federal de Mato Grosso - Cuiabá}

\author{
Paula Márcia Marques de Campos Andrade ${ }^{1 *}$; Thais Oliveira Morgado ${ }^{1}$; \\ Paulo Ricardo Mallmann²; Paulo Roberto Spiller ${ }^{1}$; Lianna Ghisi Gomes ${ }^{1}$; \\ Matias Bassinello Stocco ${ }^{1}$; Andresa de Cássia Martini ${ }^{1}$; Deise Cristine Schroder ${ }^{1}$; \\ Sandra Helena Ramiro Correa ${ }^{3}$; Roberto Lopes de Souza ${ }^{4}$
}

\begin{abstract}
Control of oral lesions contributes directly to the health, survival and welfare of captive animals. In order to investigate the occurrence of oral diseases in neotropical wild carnivores kept at the zoo at the Federal University of Mato Grosso - Cuiabá, we evaluated 31 oral cavities from three families of carnivores (Felidae, Canidae and Procyonidae) between July 2012 and June 2013. Twelve coatis (Nasua nasua), three raccoons (Procyon cancrivorus), two maned wolves (Chrysocyon brachyurus), six crab-eating fox (Cerdocyon thous), one hoary fox (Pseudalopex vetulus), three ocelots (Leopardus pardalis), one cougar (Puma concolor) and three wild cats (Puma yagouaroundi, Leopardus wiedii and Leopardus colocolo) were reviewed. The most frequent lesions were dental absences 21/31 (67.7\%), dental fractures 20/31 (64.5\%) and tooth wear 19/31 (61.3\%), which were suggestive of trauma caused from stress. Of lesser importance, we also observed occurrence of dental calculus grade I in 18/31 $(58 \%)$, caries $1 / 31(3.2 \%)$, foreign bodies $2 / 31(6.4 \%)$, orofacial fistulas $1 / 31(3.2 \%)$, hyperplasia in the oral mucosa 1/31 (3.2\%), dental dimming 3/31 (9.7\%) and chafing of the soft tissue 5/31 (16.1\%). Therefore, it was concluded that environmental enrichment strategies and oral routine evaluation must be implemented to ensure the welfare of these animals, reducing local and systemic adverse effects of oral lesions. The diet has been successful in preventing periodontal disease, suggesting that this diet for the captive animals in the institution should be maintained.
\end{abstract}

Key words: Animal welfare, veterinary dentistry, wildlife

\section{Resumo}

O controle de lesões odontoestomatológicas contribui diretamente na saúde, sobrevivência e bem-estar dos animais cativos. Este estudo objetivou investigar a ocorrência de afecções orais em carnívoros selvagens neotropicais mantidos no zoológico da Universidade Federal de Mato Grosso - Cuiabá. Foram

\footnotetext{
1 Pós-Graduandos em Ciências Veterinárias, Universidade Federal de Mato Grosso, UFMT, Cuiabá, MT, Brasil. E-mail: paulamarciavet@gmail.com; thaismorgado@gmail.com; paulo_spiller@hotmail.com; liannaghisi@gmail.com; matiasnave@ hotmail.com; andresa.martini@hotmail.com; deisetine@hotmail.com

2 Discente do Curso de Graduação em Medicina Veterinária, UFMT, Cuiabá, MT, Brasil. E-mail: pmallmann1@gmail.com

3 Prof $^{a}$ Dr $^{\mathrm{a}}$, Dept ${ }^{\circ}$ de Animais Selvagens, UFMT, Cuiabá, MT, Brasil. E-mail: correasandrahelena@gmail.com

4 Prof. Dr, Dept ${ }^{\circ}$ de Clínica e Cirurgia Veterinária, UFMT, Cuiabá, MT, Brasil. E-mail: lopesdesouza.roberto@gmail.com

* Author for correspondence
} 
avaliadas 31 cavidades orais de três famílias (Felidae, Canidae e Procyonidae), no período de julho de 2012 a junho de 2013, sendo doze quatis (Nasua nasua), três mãos-peladas (Procyon cancrivorus), dois lobos-guarás (Chrysocyon brachyurus), seis lobinhos (Cerdocyon thous), uma raposa (Pseudalopex vetulus), três jaguatiricas (Leopardus pardalis), uma onça-parda (Puma concolor) e três gatos selvagens (Puma yaguaroundi, Leopardus wiedii e Leopardus colocolo). As lesões mais frequentes foram ausências dentárias 21/31 (67,7\%), fraturas dentárias 20/31 (64,5\%) e desgastes dentários 19/31 (61,3\%), as quais foram sugestivas de traumas, proveniente de estresse. Foram ainda observados com menor expressão, acúmulo de cálculo dentário grau I em 18/31 (58\%), cárie 1/31 (3,2\%), corpo estranho 2/31 (6,4\%), fístula orofacial $1 / 31(3,2 \%)$, hiperplasia na mucosa oral $1 / 31(3,2 \%)$, escurecimento dental $3 / 31$ $(9,7 \%)$ e escoriações em tecidos moles 4/31 (12,9\%). Logo, foi possível concluir que estratégias de enriquecimento ambiental e rotina de avaliação odontoestomatológica são importantes para garantir o bem-estar desses animais, reduzindo as consequências negativas locais e sistêmicas das lesões orais. A dieta utilizada mostrou-se eficiente na prevenção de doença periodontal, sugerindo a manutenção da mesma na alimentação dos animais cativos da instituição.

Palavras-chave: Animais selvagens, bem-estar animal, odontologia veterinária

\section{Introduction}

The oral cavity, teeth and associated tissues are structures of fundamental importance for the health of all animals, both domestic and wild (PACHALY, 2007). This structure is the beginning of the digestive system and its well-being is essential for efficiency in processing food and nutrients. Oral cavity health is directly linked to the well-being and maintenance of any individual's life, because oral diseases have been associated with systemic debilitating diseases (PACHALY; GIOSO, 2001).

In animals kept in captivity, injuries to the oral cavity can be the result of one or more factors such as trauma, inadequate diet, changes in tooth development, malocclusion, dental degeneration (wear, abrasion, erosion and resorption) and action of pathogenic microorganisms that destroy tissues and generate calcified soft tissue inflammation (WIGGS; LOBPRISE, 1997).

Dental trauma often occurs in carnivores kept in captivity, the trauma commonly begins with fractures or dental abrasion and consequently the exposure of the dental pulp or tooth loss. Causes include biting enclosure obstacles (grids, screens, feeders and poles), fighting between conspecifics and trauma in capture. Once exposed, the pulp undergoes bacterial contamination, leading to pulp necrosis, dentoalveolar abscessation and other associated disorders such as increased volume and extraoral fistulas (PACHALY, 2007).
Periodontal disease is a highly prevalent disease and is characterised by chronic periodontal immunological inflammation that results in progressive loss of gingival tissue, periodontal ligament and adjacent alveolar bone support. It is also one of the causes of tooth loss, infection and oral discomfort in captive animals (GIOSO, 2007).

Affected animals with odontostomatological lesions demonstrate clinical signs such as decreased appetites, weight loss, loss of food during mastication, facial swelling, fistulas, signs of pain or discomfort, attitude changes, and changes in diet selectivity (WIGGS; LOBPRISE, 1997). The most severe oral diseases lead to decreased food and water intake, allowing potential death of the animal (GIOSO; ROSSI JÚNIOR, 2001).

Thus, considering the importance of oral cavity disease and the paucity of data in the mid-west region of Brazil, this study aimed to identify the occurrence, type and predisposing risk factors of dental injuries in neotropical wild carnivores in captivity at the zoo of the Federal University Mato Grosso - Cuiabá.

\section{Material and Methods}

We evaluated the oral cavities of 31 wild animals of the order Carnivora that are kept in captivity at the zoo UFMT, city of Cuiabá - MT. The animals were examined between July 2012 and June 2013, 
and belonged to 10 species in 3 families. From the Felidae family, three ocelots (Leopardus pardalis), a cougar (Puma concolor), a jaguarundi (Puma yagouaroundi), a Margay (Leopardus wiedii) and a pampas cat (Leopardus colocolo) were evaluated, for a total of seven individuals. In the Canidae family, nine individuals were evaluated, including six crab-eating foxes (Cerdocyon thous), a hoary fox (Pseudalopex vetulus) and two maned wolves (Chrysocyon brachyurus). Finally the Procyonidae family added fifteen animals to be evaluated, including twelve coatis (Nasua nasua) and three crab-eating raccoons (Procyon cancrivorus).

The odontostomatological reviews were performed at the same time as the zoo's routine procedures, at which time the animals were subjected to chemical restraint for clinical assessment, collection of biological material and microchip identification.

The evaluation of the oral cavity was performed according to the protocol described by Gorrel (2010) and Roza (2011), followed by an extraoral evaluation by observing the shape and contour of the head (asymmetry can increase volume, the presence of lumps or fistulas, size of lymph nodes and salivary glands), changes in motion occlusion and the temporomandibular joint. The intraoral clinical evaluation included observation of the integrity of the lips, mucous membranes, palate, tongue, salivary glands, mandible and maxilla, gums, neoformation and anatomical changes. And finally, the individual was assessed for the presence of periodontal lesions, bacterial plaque, subgingival calculations, decalcification, wear, mobility, abnormalities in tooth surface and dental fractures with or without pulp exposure. At this stage, missing teeth were evaluated, and supernumerary teeth and morphological changes (changes size or fused teeth), dental positioning (spins or crowding) and tooth enamel (hypoplasia) were noted.

All observed changes were noted in individual odontograms with diagrammatic representations of dentition for each specimen (GORREL, 2010). We also tabulated animal identification data (species, microchip number, estimated age, weight and sex) as well as information on management of the enclosures and food of these individuals.

\section{Results and Discussion}

We reviewed 31 neotropical wild carnivores kept in captivity and found various oral lesions (Table 1). The most frequent injuries were missing teeth $21 / 31$ (67.7\%), dental fractures 20/31 (64.5\%) and tooth wear 19/31 (61.3\%). Advanced periodontal disease was not observed. The most represented periodontal lesion was dental calculus 18/31 (58\%), but all affected specimens were only grade I (Figure 1. A). Other periodontal lesions found included receding gums, dental plaque, gingivitis, tooth mobility, exposed furcation, exposed root, periodontal pocketing and gingival hyperplasia. Scratches were also observed in the soft tissue 4/31 (12.9\%), as well as decay $1 / 31$ (3.2\%) (Figure 1. B), foreign bodies $2 / 31(6.4 \%)$, oral mucosal hyperplasia $1 / 31(3.2 \%)$, dental dimming $3 / 31$ (9.7\%), orofacial fistulas $1 / 31$ (3.2\%) and orthodontic change 1/31 (3.2\%).

Of the traumatic injuries observed, 71 fractured teeth, 19 (26.8\%) without pulp exposure, 50 dead exposed pulp (70.4\%) and 2 with alive exposed pulp $(2.8 \%)$ were found.

Corroborating with Cuozzo et al. (2010), the severity of dental wear was evident in older animals, and the raccoons (Procyon cancrivorus) were the most affected.

In coatis (Nasua nasua) and raccoons (Procyon cancrivorus), the teeth 411 (3rd molar lower right) and 311 (3rd molar lower left) were missing, which is represented by the formula $2 x$ (I 3/3; C 1/1; PM $4 / 4 ; \mathrm{M} 2 / 2)=40$ teeth, as previously described by Freitas et al. (2008), Pieri et al. (2011), and Bianchi et al. (2013).

According to Silva et al. (2010), a way to evaluate the estimated age of an animal is by measuring the 
pulp canal. Similarly, Gioso (2007) and Wiggs and Lobprise (1997) state that the higher the pulp canal, the younger the animal and the narrower the pulp canal, the older the animal. Furthermore, one of the coatis showed severe fractures in its mandibular canines, in which the pulp was visible with large necrotic regions, indicating that they were broken while young and that the coati had lived with this discomfort for a long time.

Table 1. Lesions found in the oral cavity of 31 neotropical wild carnivores in captivity at the zoo UFMT - Cuiaba, July 2012 to June 2013.

\begin{tabular}{lccc}
\hline \multicolumn{1}{c}{ LESION } & NUMBER of ANIMALS & PERCENT & TYPE OF INJURY \\
\hline Missing teeth & 21 & $67.7 \%$ & \\
Dental fractures & 20 & $64.5 \%$ & Injury traumatic causes \\
Tooth wear & 19 & $61.3 \%$ & \\
Calculus & 18 & $58.0 \%$ & \\
Receding gums & 10 & $32.2 \%$ & \\
Dental plaque & 8 & $25.8 \%$ & \\
Gingivitis & 6 & $19.3 \%$ & Periodontitis \\
Tooth mobility & 6 & $19.3 \%$ & \\
Exposed furcation & 3 & $9.7 \%$ & \\
Exposed root & 2 & $6.4 \%$ & \\
Periodontal pocket & 2 & $6.4 \%$ & \\
Gingival hyperplasia & 2 & $6.4 \%$ & Dental injuries \\
Dental darkening & 3 & $9.7 \%$ & \\
Caries & 1 & $3.2 \%$ & \\
Orthodontic amendment & 1 & $3.2 \%$ & Soft tissue lesions of the \\
Abrasions in the oral mucosa & 4 & $12.9 \%$ & oral cavity and face \\
Foreign body & 2 & $6.4 \%$ & \\
Orofacial fistula & 1 & $3.2 \%$ & \\
Mucosal hyperplasia & 1 & $3.2 \%$ & \\
\hline
\end{tabular}

Figure 1. A. Grade I dental calculus and gum hyperplasia corresponding to the 4th premolar lower right in the maned wolf. B. Grade II wear and presence of caries in the 1st and 2nd upper left molar in the coati.




Freitas et al. (2008) evaluated coatis (Nasua nasua) kept in captivity and found a high presence of periodontal disease, dental plaque $(71.4 \%)$ and gingivitis (71.4\%). However, this study found low presence of periodontal disease and when present was only in small localised areas.

In the groups of canids and raccoons, the most relevant lesions were suggestive of traumatic causes. In canids, fractures were common in canines and premolars and incisors were most commonly missing, and in raccoons, fractures affected only the canine teeth and incisors and premolars were most commonly missing.

Rossi Júnior et al. (2007) conducted a comparative study of free and captive jaguars and determined that all captive animals showed varying degrees of periodontal disease, while wild animals showed no periodontal disease. In agreement with this information, the felines in this study had mild gingivitis and dental calculus, and one of these animals showed localised periodontal changes including gingival recession and partial root exposure on the 3rd left premolar (Figure 2. A), and gingival hyperplasia next to the lower left canine approximately $1 \mathrm{~cm}$ in diameter (Figure 2. B). The fractures had little importance in this group because they were discrete, with two dental fractures occurring in an ocelot (Leopardus pardalis) and a puma (Puma concolor) with small cusp fractures on four of its canines that affected only the enamel.

Figure 2. A. Ocelot with gingival recession and root exposure in the 3rd left premolar. B. fracture with pulp exposure in a dead canine bottom right, gingival hyperplasia in the rostral portion of the left jaw and absence of the right mandibular lateral incisor.

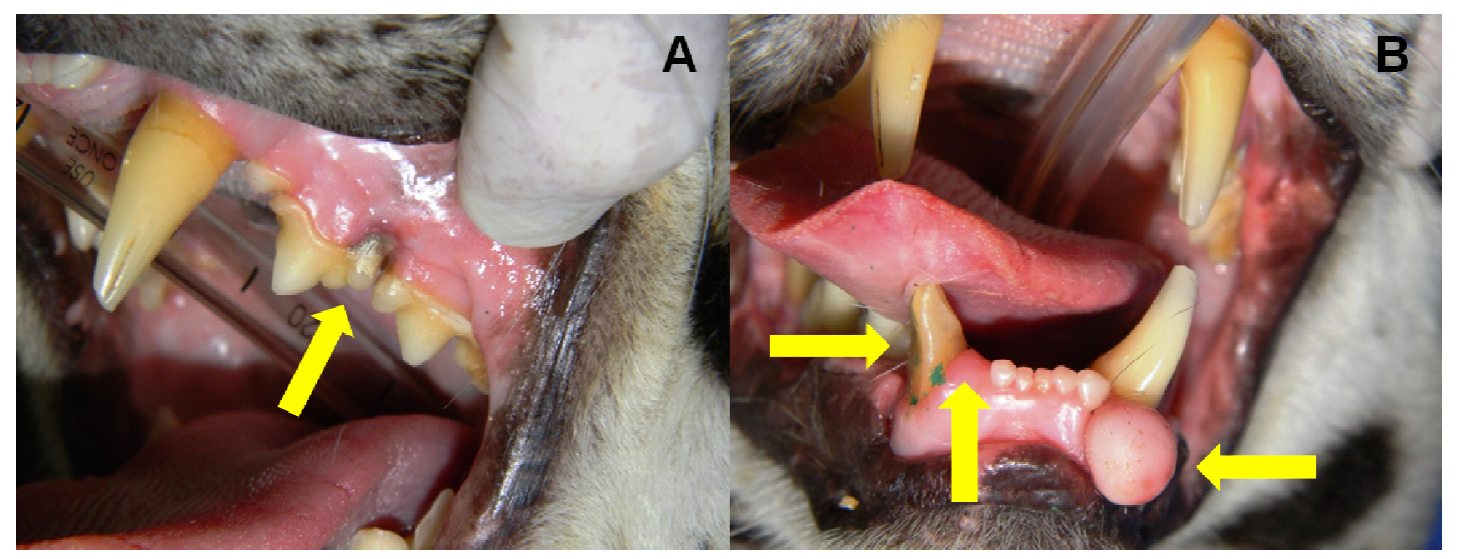

When compared with other studies, this study found a higher incidence of lesions compatible with traumatic factors, i.e., wear, absences and dental fractures than lesions associated with periodontal disease, orthognathic problems, persistence of deciduous teeth or dental anomalies. This can be explained by the difference in microhabitat and/or food involved in each study. According Pachaly (2007), traumatic injuries may be related to chronic stress, which leads to biting habits or fights, to trauma during restraint or to falls, while the periodontal lesions may be related to the type of diets offered.

The traumatic injuries in this study were identified as a result of stress and therefore can be corrected through environmental enrichment measures. Claxton (2011) and Vucinic (2009) state that simple actions can reduce the stress of captive animals. Environmental enrichment strategies are used to improve both the physiological and psychological well-being of captive animals, 
which can be achieved by increasing the expression of natural behaviour and reducing abnormal behaviour.

The diets fed to these animals evaluated contained chopped meat and stunned live prey such as small rodents and pigeons. For canids and raccoons, fruits, eggs, raw fish and pet food specific to the species were offered. This composition of the diet for different groups explains dental conditions described, as it offers greater masticatory exercise and a breadth of texture (chopped meat and live animals), providing cleaning of the periodontal surfaces through chewing and promoting oral health of the animals.

\section{Conclusion}

Based on the data obtained, it was concluded that the oral lesions most commonly present in these neotropical carnivores were tooth absence, dental fracture and wear, affecting more than $60 \%$ of individuals. These lesions are associated with traumatic factors such as fights, trauma during restraint and abnormal behaviour (biting objects) caused by stress in captivity. Therefore, environmental enrichment strategies and routine evaluation of the oral cavity are important to ensure the welfare of the animals, by reducing local and systemic adverse effects of oral lesions. The low incidence of periodontal disease was due to the different textures of food present in the diet, suggesting that this diet for the captive animals in the institution should be maintained.

\section{Ethics and Biosafety Committee}

This project was approved by the Ethics Committee on Animal Use (CEUA) of the Federal University of Mato Grosso, Protocol $N^{\circ}$ 23108.019454/12-3.

\section{References}

BIANCHI, M. A. F.; MAYORGA, L. F. S. P.; CASTRO, A. P. A.; ROSSI JÚNIOR, J. L. Estudo das alterações ante-morte da cavidade oral de mãos-peladas (Procyon cancrivorus) de vida livre e de cativeiro. Pesquisa Veterinária Brasileira, Rio de Janeiro, v. 33, n. 5, p. 651661, 2013.

CLAXTON, A. M. The potential of the human-animal relationship as an environmental enrichment for the welfare of zoo-housed animals. Applied Animal Behaviour Science, Philadelphia, v. 133, n. 1-2, p. 1-10, 2011.

CUOZZO, F. P.; SAUTHER, M. L.; GOULD, L.; SUSSMAN, R. W.; LYNNE, M.; VILLERS, L. M.; LENT, C. Variation in dental wear and tooth loss among known-aged, older ring-tailed lemurs (Lemur catta): a comparison between wild and captive individuals. American Journal of Primatology, Hoboken, v. 72, n. 11, p. 1026-1037, 2010.

FREITAS, E. P.; RAHAL, S. C.; TEIXEIRA, C. R.; TEIXEIRA, R. H. F.; MENDES, G. M. T.; GIOSO, M. A. Oral cavity evaluation and dental chart registration of coati (Nasua nasua) in captivity. Journal of Veterinary Dentistry, Boise, v. 25, n. 2, p. 110-117, 2008.

GIOSO, M. A. Odontologia veterinária para o clínico de pequenos animais. 2. ed. São Paulo: Manole, 2007. $142 \mathrm{p}$.

GIOSO, M. A.; ROSSI JÚNIOR, J. L. Prevalence of oral lesions in Puma concolor and Panthera onca in the State of São Paulo, Brazil. In: ANNUAL VETERINARY DENTAL FORUM, 15., 2001, Texas. Anais... Texas: Nashville, TN, 2001. p. 208.

GORREL, C. Odontologia em pequenos animais. Rio de Janeiro: Elsevier, 2010. 240 p. (Série clínica veterinária na prática).

PACHALY, J. R. Odontoestomatologia. In: CUBAS, Z. S.; SILVA, J. C. R.; CATÃO-DIAS, J. L. Tratado de animais selvagens. São Paulo: Roca, 2007. p. 1068-1091.

PACHALY, J. R.; GIOSO, M. A. The oral cavity. In: FOWLER, M. E.; CUBAS, Z. S. Biology, medicine and surgery of South American wild animals. Ames: Iowa State University Press, 2001. p. 1-15.

PIERI, N. C. G.; MANÇANARES, C. A. F.; BERTASSOLI, B.; LIMA, J. M. N.; THOMAZ, J. M.; CARVALHO, A. F. Classificação morfofuncional dos dentes de quati, Nasua nasua. Pesquisa Veterinária Brasileira, Rio de Janeiro, v. 31, n. 5, p. 447-451, 2011. 
ROSSI JÚNIOR, J. L.; GIOSO, M. A.; DOMINGUESFALQUEIRO, L. M. Estudo comparativo sobre prevalência de doença periodontal em Panthera onca mantida em cativeiro e em indivíduos de natureza. Pesquisa Veterinária Brasileira, Rio de Janeiro, v. 27, n. 5, p. 209-214, 2007.

ROZA, M. R. Exame bucal em cães e gatos - parte 1 cavidade oral. Medvep - Revista Cientifica de Medicina Veterinária, Curitiba, v. 9, n. 28, p. 77-82, 2011.
SILVA, E. L. F.; LEITE, F. L. G.; SOUZA, T. D.; ROSSI JÚNIOR, J. L.; MARCHESI, M. D.; ALVES, D. C. Avaliação da idade em cachorros-do-mato, Cerdocyon thous (Linnaeus, 1758), por meio da mensuração do diâmetro do canal pulpar. Revista Natureza on line, Santa Teresa, v. 8, n. 3, p. 114-116, 2010.

VUCINIC, M. Environmental enrichment in farm, zoo, companion and experimental animals. Veterinarski Glasnik, Belgrado, v. 63, n. 3-4, p. 227-236, 2009.

WIGGS, R. B.; LOBPRISE, H. B. Veterinary dentistry: principles and practice. Philadelphia: Lippincott-Raven, 1997. $748 \mathrm{p}$. 
